\title{
Role of Chloride and Intracellular pH on the Activity of the Rat Hepatocyte Organic Anion Transporter
}

\author{
Albert D. Min, Kirsten L. Johansen, Celeste G. Campbell, and Allan W. Wolkoff
}

Liver Research Center, Albert Einstein College of Medicine, Bronx, New York 10461

\begin{abstract}
Previous studies in cultured rat hepatocytes revealed that initial uptake of sulfobromophthalein (BSP) was markedly reduced upon removal of $\mathrm{Cl}^{-}$from the medium. In the present study, unidirectional $\mathrm{Cl}^{-}$gradients were established in shortterm cultured rat hepatocytes and their effect on BSP uptake was determined. These investigations revealed that BSP uptake requires external $\mathrm{Cl}^{-}$and is not stimulated by unidirectional $\mathrm{Cl}^{-}$gradients, suggesting that BSP transport is not coupled to $\mathrm{Cl}^{-}$transport. In contrast, BSP transport is stimulated by an inside-to-outside $\mathrm{OH}^{-}$gradient, consistent with $\mathrm{OH}^{-}$exchange or $\mathrm{H}^{+}$cotransport. As the presence of $\mathrm{Cl}^{-}$is essential for but not directly coupled to BSP transport, binding of ${ }^{35} \mathrm{~S}$ BSP to hepatocytes was determined at $4^{\circ} \mathrm{C}$. This revealed an $\sim 10$-fold higher affinity of cells for BSP in the presence as compared to the absence of $\mathrm{Cl}^{-}\left(K_{\mathrm{a}}=3.2 \pm 0.8\right.$ vs. $0.42 \pm 0.09$ $\left.\mu \mathrm{M}^{-1} ; P<0.02\right)$. Affinity of $\mathrm{BSP}$ for albumin was $\mathrm{Cl}^{-}$-independent, and was $\sim 10 \%$ of its affinity for cells in the presence of $\mathrm{Cl}^{-}$. These results indicate that extracellular $\mathrm{Cl}^{-}$modulates the affinity of BSP for its hepatocyte transporter. (J. Clin. Invest. 1991. 87:1496-1502.) Key words: sulfobromophthalein • cultured hepatocytes • transport • albumin binding • chloride transport
\end{abstract}

\section{Introduction}

The organic anions bilirubin and sulfobromophthalein (BSP) ${ }^{1}$ circulate tightly bound to albumin $(1,2)$ and are extracted rapidly from this carrier by hepatocytes $(3,4)$. After transport into cell cytosol, they bind to soluble proteins, primarily glutathione (GSH)-S-transferases $(5,6)$ prior to conjugation and excretion into bile. Uptake of bilirubin and BSP has kinetics suggesting carrier mediation. Although several putative transport proteins have been identified (7-11), their function in organic anion transport is not well defined. Previous studies in cultured rat hepatocytes and isolated perfused rat liver have revealed that initial uptake of these organic anions is markedly reduced upon removal of $\mathrm{Cl}^{-}$from the medium (12). There is no requirement for specific inorganic cations, as initial uptake in the

Address correspondence to Allan W. Wolkoff, M.D., Liver Research Center, Albert Einstein College of Medicine, 1300 Morris Park Ave., Bronx, NY 10461.

Received for publication 6 July 1990 and in revised form $26 \mathrm{No}$ vember 1990.

1. Abbreviations used in this paper: BSP, sulfobromophthalein; GSH, glutathione; SFM, serum-free medium.

J. Clin. Invest.

(c) The American Society for Clinical Investigation, Inc.

0021-9738/91/05/1496/07 \$2.00

Volume 87, May 1991, 1496-1502 presence of $\mathrm{Na}^{+}, \mathrm{K}^{+}$, or $\mathrm{Li}^{+}$is unchanged $(12,13)$. The mechanism by which inorganic anions such as $\mathrm{Cl}^{-}$influence hepatocyte organic anion uptake is not known. $\mathrm{A} \mathrm{Na}^{+}$-independent $\mathrm{Cl}^{-}$transport system was previously described in intact rat liver and cultured rat hepatocytes $(14,15)$, but its possible relationship to $\mathrm{Cl}^{-}$-dependent organic anion uptake remains unknown.

The present investigation was undertaken to determine whether hepatocyte BSP transport is linked to $\mathrm{Cl}^{-}$transport. Procedures have been devised to establish transient unidirectional $\mathrm{Cl}^{-}$gradients in short-term cultured rat hepatocytes and the effect of such gradients on initial uptake of ${ }^{35} \mathrm{~S}$-BSP has been determined.

\section{Methods}

\section{Isolation and short-term culture of rat hepatocytes}

Rat hepatocytes were isolated from 200-250-g male Sprague-Dawley rats (Taconic Farms, Germantown, NY) after perfusion of the liver with collagenase A (Boehringer Mannheim Biochemicals, Indianapolis, IN). Cells were suspended in medium consisting of Waymouth's $752 / 1$ (Gibco, Grand Island, NY) containing $25 \mathrm{mM}$ Hepes, pH 7.2, $5 \%$ heat-inactivated FBS (Hyclone Labs Inc., Logan, UT), $1.7 \mathrm{mM}$ additional $\mathrm{CaCl}_{2}, 5 \mu \mathrm{g} / \mathrm{ml}$ bovine insulin (Sigma Chemical Co., St. Louis, MO), $100 \mathrm{U} / \mathrm{ml}$ penicillin (Gibco), and $0.1 \mathrm{mg} / \mathrm{ml}$ streptomycin (Gibco). $\sim 1.5 \times 10^{6}$ cells in $3 \mathrm{ml}$ were placed in $60-\mathrm{mm}$ Lux culture dishes (Nunc, Inc., Naperville, IL), and cultured in $5 \% \mathrm{CO}_{2}$ atmosphere at $37^{\circ} \mathrm{C}$. $\sim 2 \mathrm{~h}$ later, medium was changed and cells were cultured for an additional $16-18 \mathrm{~h}(12,16)$. Cell viability was $>90 \%$ as judged by Trypan blue exclusion.

\section{Uptake of ${ }^{35} S$-BSP by cultured hepatocytes}

Uptake of ${ }^{35} \mathrm{~S}$-BSP by overnight cultured hepatocytes was determined as previously described (12). In some experiments, uptake of BSP was determined in cultured cells within 1-2 h of cell isolation. In brief, cells were washed twice with $1.5 \mathrm{ml}$ of modified serum-free medium (SFM), consisting of $135 \mathrm{mM} \mathrm{NaCl}, 1.2 \mathrm{mM} \mathrm{MgCl}_{2}, 0.81 \mathrm{mM} \mathrm{MgSO}_{4}, 27.8$ $\mathrm{mM}$ glucose, $2.5 \mathrm{mM} \mathrm{CaCl}$, and $25 \mathrm{mM}$ Hepes adjusted to $\mathrm{pH} 7.2$ with solid Tris base. $1 \mathrm{ml}$ of $0.1 \%(14.7 \mu \mathrm{M}$ ) BSA (fraction V, Sigma Chemical Co.) in SFM was added to each plate, which was then incubated for $15 \mathrm{~min}$ at 4 or $37^{\circ} \mathrm{C} .{ }^{35} \mathrm{~S}-\mathrm{BSP}(2,500-4,000 \mathrm{mCi} / \mathrm{mmol})$ was prepared as described previously (17) and was dissolved in distilled water. Sufficient unlabeled BSP was added to make an $80-\mu \mathrm{M}$ BSP stock solution containing $\sim 10^{7} \mathrm{dpm} / \mathrm{ml}$. A $10-\mu$ l aliquot of this stock solution was added to $1 \mathrm{ml}$ of albumin-containing medium on each plate and incubation was continued at 4 or $37^{\circ} \mathrm{C}$ for various periods. After incubation with ${ }^{35} \mathrm{~S}-\mathrm{BSP}$, plates were washed twice at $4^{\circ} \mathrm{C}$ with $1.5 \mathrm{ml}$ of SFM and incubated for $5 \mathrm{~min}$ in $1.5 \mathrm{ml}$ of $5 \%$ BSA in $20 \mathrm{mM}$ PBS, pH 7.4 at $4^{\circ} \mathrm{C}$ to displace surface-bound radioactivity. Plates were then washed three times with $1.5 \mathrm{ml}$ of SFM at $4^{\circ} \mathrm{C}$. Cells were harvested, and radioactivity was quantified in a RackBeta model 1217 liquid scintillation counter (LKB Instruments, Gaithersburg, MD), after addition of $10 \mathrm{ml}$ of Hydrofluor (National Diagnostics, Inc. Somerville, NJ). Replicate plates were washed and harvested in PBS for determination of cellular protein by the method of Lowry et al. (18), or by the bicinchoninic acid method (Pierce Chemical Co., Rockford, IL) using BSA as standard. 
Effect of valinomycin, salt substitution, and osmolarity on initial uptake of ${ }^{35} S-B S P$

Medium was prepared in which $\mathrm{NaCl}$ was substituted isosmotically by $\mathrm{KCl}$. Previous studies in which hepatocytes were depolarized in $\mathrm{KCl}$ substituted medium, suggested that BSP uptake was not electrogenic (12). To confirm these findings, cultured hepatocytes were preincubated for $15 \mathrm{~min}$ at $37^{\circ} \mathrm{C}$ in $\mathrm{NaCl}$-containing medium. Initial uptake of ${ }^{35} \mathrm{~S}-\mathrm{BSP}$ was determined over $5 \mathrm{~min}$ in $\mathrm{KCl}$-substituted medium in the presence or absence of $10 \mu \mathrm{M}$ valinomycin. Uptake in the absence of valinomycin was also determined in choline chloride and NaI-substituted media. Previous studies (12) revealed a marked reduction in initial BSP uptake upon isosmotic substitution of $\mathrm{NaCl}$ in medium by sucrose. Chloride-free, sucrose-substituted medium may lead to osmotic shrinkage of cells $(19,20)$. To determine the influence of cell shrinkage on initial BSP uptake, studies were also performed in cells preincubated for $15 \mathrm{~min}$ at $37^{\circ} \mathrm{C}$ in normal NaCl-containing medium to which $1 \mathrm{M}$ mannitol had been added.

\section{Uptake of ${ }^{36} \mathrm{Cl}$ by short-term cultured rat hepatocytes}

$\mathrm{H}^{36} \mathrm{Cl}(19.4 \mathrm{mCi} / \mathrm{g})$ was purchased from New England Nuclear, Boston, MA. Cultured hepatocytes were washed twice at room temperature with $1.5 \mathrm{ml}$ of sucrose-substituted medium and incubated for 30 min at $37^{\circ} \mathrm{C}$. They were then washed twice with $1.5 \mathrm{ml}$ of sucrose-substituted medium at 37 or $4^{\circ} \mathrm{C}$, and incubated for varied times in $1 \mathrm{ml}$ of $\mathrm{NaCl}$-containing medium with ${ }^{36} \mathrm{Cl}(1 \mu \mathrm{Ci} / \mathrm{ml})$ at 37 or $4^{\circ} \mathrm{C}$. The medium was removed, and cells were washed with ice-cold $\mathrm{NaCl}$-containing medium. Preliminary studies were performed to determine the number of washes necessary to remove surface-adsorbed ${ }^{36} \mathrm{Cl}$. Cells were then harvested, and radioactivity was determined. To insure that cell-associated ${ }^{36} \mathrm{Cl}$ was free and not membrane-bound, cells were disrupted by sonication after washing and centrifuged at $100,000 \mathrm{~g}$ for $60 \mathrm{~min}$. Radioactivity was determined in the supernatant and pellet.

\section{Eflux of ${ }^{36} \mathrm{Cl}$ from cultured hepatocytes}

Previous studies indicated that incubation of cells $(14,15)$ or perfused liver $(21,22)$ in $\mathrm{Cl}^{-}$-free medium depleted both intracellular and extracellular $\mathrm{Cl}^{-}$. To deplete intracellular $\mathrm{Cl}^{-}$, cells were incubated in sucrose-substituted medium for $30 \mathrm{~min}$ at $37^{\circ} \mathrm{C}$. They were then loaded with ${ }^{36} \mathrm{Cl}$ by incubation for $60 \mathrm{~min}$ at $37^{\circ} \mathrm{C}$ in $1 \mathrm{ml}$ of $\mathrm{NaCl}$-containing medium to which was added $2 \mu \mathrm{Ci}$ of ${ }^{36} \mathrm{Cl}$. Preliminary studies revealed that cell-associated ${ }^{36} \mathrm{Cl}$ was maximal by this time. Cells were then washed five times with $1.5 \mathrm{ml}$ of ice-cold sucrose-substituted medium. Efflux of ${ }^{36} \mathrm{Cl}$ from these preloaded cells was instituted after incubation at 4 or $37^{\circ} \mathrm{C}$ for various times in $1 \mathrm{ml}$ of sucrose-substituted medium. Cells were then washed five times with $1.5 \mathrm{ml}$ of ice-cold $\mathrm{NaCl}$-containing medium, harvested, and radioactivity was determined.

\section{Influence of $\mathrm{Cl}^{-}$gradients on uptake of ${ }^{35} \mathrm{~S}$-BSP}

To examine whether chloride gradients influence hepatic organic anion uptake, initial uptake of ${ }^{35} \mathrm{~S}-\mathrm{BSP}$ was determined under four conditions: (a) normal content of extracellular $\mathrm{Cl}^{-}\left(\mathrm{Cl}_{\mathrm{e}}\right)$ and intracellular $\mathrm{Cl}^{-}$ $\left(\mathrm{Cl}_{\mathrm{i}}\right) ;(b) \mathrm{Cl}_{\mathrm{i}}>\mathrm{Cl}_{e} ;(c) \mathrm{Cl}_{\mathrm{e}}>\mathrm{Cl}_{\mathrm{i}}$; and $(d)$ depletion of both $\mathrm{Cl}_{\mathrm{i}}$ and $\mathrm{Cl}_{e}$. Cultured hepatocytes were washed and incubated in $3 \mathrm{ml}$ of either $\mathrm{NaCl}$-containing or sucrose-substituted medium at $37^{\circ} \mathrm{C}$ for $30 \mathrm{~min}$ Each group of cells was then washed twice with $1.5 \mathrm{ml}$ of the initial medium, followed by incubation with $0.1 \%$ BSA and $0.8 \mu \mathrm{M}^{35} \mathrm{~S}-\mathrm{BSP}$ in $1 \mathrm{ml}$ of either $\mathrm{NaCl}$-containing or sucrose-substituted medium at 4 or $37^{\circ} \mathrm{C}$ for $1 \mathrm{~min}$. After washing twice with $1.5 \mathrm{ml}$ of ice-cold SFM, cells were incubated in $1.5 \mathrm{ml}$ of $5 \% \mathrm{BSA}$ at $4^{\circ} \mathrm{C}$ for $5 \mathrm{~min}$. Cells were washed three times with $1.5 \mathrm{ml}$ of SFM at $4^{\circ} \mathrm{C}$, harvested, and radioactivity was determined.

\section{Binding of ${ }^{35} S$-BSP to the surface of hepatocytes}

Binding studies were performed at BSP concentrations of 0.08-3.2 $\mu \mathrm{M}$ at $4^{\circ} \mathrm{C}$ in the presence of a 15 -fold molar excess of BSA, keeping the ratio of albumin to BSP constant to minimize changes in the fraction of unbound ligand (23). Cultured cells were washed three times with 1.5 $\mathrm{ml}$ of ice-cold $\mathrm{NaCl}$-containing or sucrose-substituted media, and incubated with $1 \mathrm{ml}$ of the appropriate mixture of ${ }^{35} \mathrm{~S}-\mathrm{BSP}$ and BSA at $4^{\circ} \mathrm{C}$ for $1 \mathrm{~min}$. They were quickly washed three times with $1.5 \mathrm{ml}$ of SFM, harvested, and radioactivity was determined.

\section{Effect of $\mathrm{Cl}^{-}$on binding of ${ }^{35} \mathrm{~S}-\mathrm{BSP}$ to $\mathrm{BSA}$}

Binding of ${ }^{35}$ S-BSP to BSA was studied by two ultrafiltration techniques. Results from each method were previously demonstrated to agree with those obtained by equilibrium dialysis (24-26), and data obtained by the two methods was identical.

Pressure ultrafiltration. Each chamber of a 22-channel plexiglas apparatus designed by Schramm (24) was loaded with 12 pmol of ${ }^{35} \mathrm{~S}$ BSP with various amounts of unlabeled BSP and $0.1 \%$ BSA in $150 \mu \mathrm{l}$ of $\mathrm{NaCl}$-containing or sucrose-substituted medium. Upper and lower chambers were separated by dialysis membranes with molecular weight cutoff of 8,000 (Spectrum Medical Industries, Inc., Los Angeles, CA). The apparatus was pressurized to 22 psi with $\mathrm{N}_{2}$ at $4^{\circ} \mathrm{C}$ and the upper chambers were free of liquid after 8-10 h. The membranes were washed thoroughly with ice-cold ethylene glycol, and radioactivity associated with dialysis membranes and aliquots of the ultrafiltrate was determined.

Centrifugal ultrafiltration. Alternatively, ${ }^{35}$ S-BSP bound to BSA was determined using a Centrifree Micropartition System (Amicon, Danvers, MA) fitted with a $30,000 \mathrm{~mol}$ wt cutoff membrane. $80 \mathrm{pmol}$ of ${ }^{35} \mathrm{~S}$-BSP with various amounts of unlabeled BSP and 0.1\% BSA in $500 \mu \mathrm{l}$ of NaCl-containing or sucrose-substituted medium was loaded onto each Centrifree reservoir, which was fitted into an SS-34 rotor (Sorvall Instruments, Newton, CT) and centrifuged at $4^{\circ} \mathrm{C}$ at 4,200 $\mathrm{rpm}$ for $10 \mathrm{~min}$. Radioactivity in $50-\mu \mathrm{l}$ aliquots of the ultrafiltrates was determined.

\section{Saturation kinetics of ${ }^{35} S$-BSP uptake by cultured hepatocytes}

Saturation kinetics of BSP uptake were studied in the presence and absence of chloride. These studies were performed at BSP concentrations of $0.08-1.6 \mu \mathrm{M}$ as described previously (12) while keeping the ratio of BSA and BSP constant. Initial uptake of ${ }^{35}$ S-BSP was determined at 4 and $37^{\circ} \mathrm{C}$ over $5 \mathrm{~min}$ in $\mathrm{NaCl}$-containing or sucrose-substituted medium. In these studies, residual cell-associated radioactivity at $4^{\circ} \mathrm{C}$ was subtracted as a blank from cell-associated radioactivity at $37^{\circ} \mathrm{C}(12)$. Data was computer analyzed by a nonlinear least squares routine (SigmaPlot version 4.0, Jandel Scientific, Corte Madera, CA) to obtain $K_{\mathrm{m}}$ and $V_{\max }$

\section{Effect of $\mathrm{pH}$ on initial uptake of ${ }^{35} \mathrm{~S}-\mathrm{BSP}$ and ${ }^{36} \mathrm{Cl}$ by cultured hepatocytes}

Modified serum-free medium was prepared as above except that the $\mathrm{pH}$ of this Hepes-buffered medium was adjusted to $\mathrm{pH} 6.0$ or 8.0 with 1 $\mathrm{N} \mathrm{NaOH}$ rather than with Tris base. Cultured cells were washed twice with $1.5 \mathrm{ml}$ of either $\mathrm{pH} 6.0$ or 8.0 medium and incubated for $30 \mathrm{~min}$ at $37^{\circ} \mathrm{C}$ in $1 \mathrm{ml}$ of the corresponding medium. In previous studies, we found that under these conditions, the intracellular $\mathrm{pH}$ equilibrated with the extracellular $\mathrm{pH}$ (27). Unidirectional $\mathrm{pH}$ gradients were formed by rapidly incubating these $\mathrm{OH}^{-}$-loaded or -depleted cells in medium of the opposite $\mathrm{pH}$. As shown previously, under these conditions, a pH gradient is maintained for several minutes (27). To perform an uptake study at $37^{\circ} \mathrm{C}$, the medium was aspirated and $1 \mathrm{ml}$ of medium containing ${ }^{36} \mathrm{Cl}$ or ${ }^{35} \mathrm{~S}-\mathrm{BSP}$ in $0.1 \% \mathrm{BSA}$ at the required $\mathrm{pH}$ was added and initial uptake determined over $5 \mathrm{~min}$ as described above. To determine cell-associated ${ }^{36} \mathrm{Cl}$ or ${ }^{35} \mathrm{~S}-\mathrm{BSP}$ at $4^{\circ} \mathrm{C}$, after the initial $30 \mathrm{~min}$ incubation at $37^{\circ} \mathrm{C}$, cells were incubated at $4^{\circ} \mathrm{C}$ for $10 \mathrm{~min}$ to insure that they were at the required temperature, and initial uptake was determined as for cells at $37^{\circ} \mathrm{C}$.

\section{Statistical analysis}

Results are expressed as mean \pm SEM. Significance was determined by Student's paired or unpaired $t$ tests as appropriate (28). Ligand binding 
data was analyzed by the LIGAND computer program of Munson and Rodbard (29).

\section{Results}

Effects of inorganic cation and anion substitution on initial uptake of ${ }^{35} S$-BSP. As previously reported (12), initial uptake of ${ }^{35} \mathrm{~S}-\mathrm{BSP}$ was unaffected by isosmotic substitution of $\mathrm{NaCl}$ by $\mathrm{KCl}, \mathrm{LiCl}$, choline $\mathrm{Cl}$, or $\mathrm{NaI}$ (Fig. 1), but was significantly reduced in $\mathrm{NaHCO}_{3}$ and $\mathrm{Na}$ gluconate. Isosmotic replacement of $\mathrm{NaCl}$ in medium by sucrose resulted in an $80 \%$ reduction in initial uptake of ${ }^{35} \mathrm{~S}-\mathrm{BSP}$ by short-term cultured hepatocytes. An identical effect was seen in hepatocytes cultured for only 1-2 $\mathrm{h}$ after preparation with an initial BSP uptake of $25 \pm 12 \%$ of control with sucrose substitution as compared to that in $\mathrm{NaCl}$ medium $(n=3, P<0.03)$. Because sucrose substitution could lead to cell shrinkage, initial uptake of BSP was determined in cells preincubated in $\mathrm{NaCl}$-containing medium to which $1 \mathrm{M}$ mannitol had been added. In this high osmolarity medium, initial uptake of BSP was $80 \pm 4 \%$ of control $(n=3, P$ $>0.1$ ), as compared to a reduction to $25 \pm 3 \%$ of control with sucrose substitution $(n=3, P<0.01)$. We have previously demonstrated that, as expected, short-term cultured rat hepatocytes are depolarized in KCl-substituted medium (12). Normal BSP uptake in this situation suggests that the process is electroneutral. In confirmation of these findings, initial ${ }^{35} \mathrm{~S}$ BSP uptake in $\mathrm{KCl}$-substituted medium containing $10 \mu \mathrm{M}$ valinomycin was $90 \pm 8 \%(n=3, P>0.05)$ of initial uptake under control conditions.

Uptake of ${ }^{36} \mathrm{Cl}$ by cultured hepatocytes. After a 30-min incubation in $135 \mathrm{mM} \mathrm{Na}{ }^{36} \mathrm{Cl}$ at $37^{\circ} \mathrm{C}$, extracellular and cell-surface adsorbed ${ }^{36} \mathrm{Cl}$ were maximally removed with five $1.5-\mathrm{ml}$ washes in $\mathrm{NaCl}$-containing medium at $4^{\circ} \mathrm{C}$ (Fig. 2). There was no reduction in residual cell-associated radioactivity with as many as nine total washes. In all subsequent ${ }^{36} \mathrm{Cl}$ studies, cells were washed five times at $4^{\circ} \mathrm{C}$. Initial uptake of ${ }^{36} \mathrm{Cl}$ by cells preincubated in $\mathrm{NaCl}$-depleted medium for $30 \mathrm{~min}$ at $37^{\circ} \mathrm{C}$

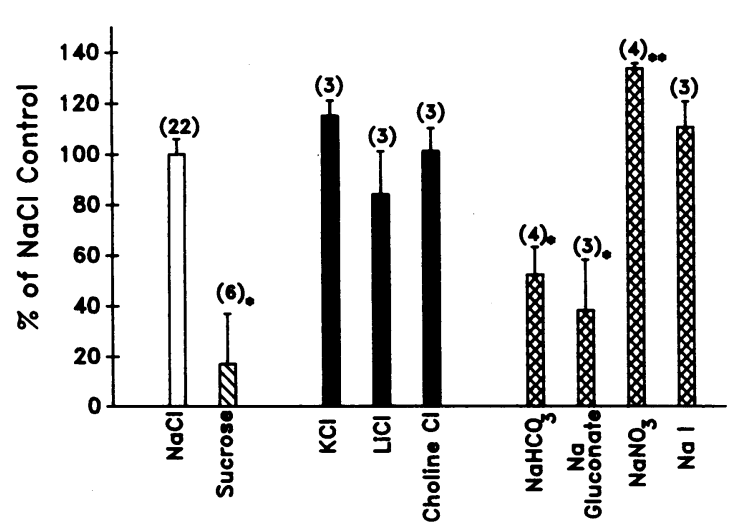

Figure 1. Effects of ion substitution on initial uptake of ${ }^{35}$ S-BSP by short-term cultured rat hepatocytes. Short-term cultured rat hepatocytes were preincubated at $37^{\circ} \mathrm{C}$ in control medium containing 135 $\mathrm{mM} \mathrm{NaCl}$ or medium in which $\mathrm{NaCl}$ was isosmotically substituted by the indicated compound. Initial uptake of ${ }^{35} \mathrm{~S}-\mathrm{BSP}(0.8 \mu \mathrm{M})$ in the presence of an 18-fold molar excess of BSA was then determined as described in Methods and expressed as a percent of that in $\mathrm{NaCl}$ medium. Data represent mean \pm SEM. The number of studies is in parentheses. This figure represents a compilation of data presented in reference 12 and new data from this study. ${ }^{*} P<0.001$. ${ }^{* *} P<0.002$.

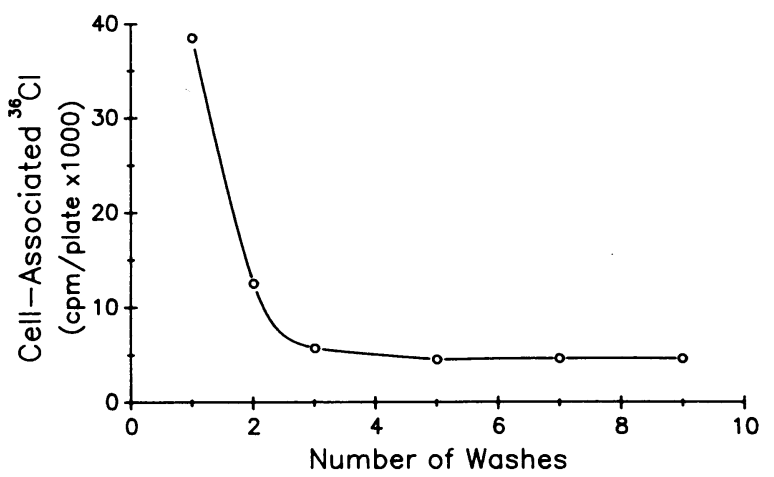

Figure 2. Effect of number of washes on cell-associated ${ }^{36} \mathrm{Cl}$. Cultured hepatocytes were washed with sucrose-substituted medium and incubated for $30 \mathrm{~min}$ in $135 \mathrm{mM} \mathrm{Na}{ }^{36} \mathrm{Cl}$ at $37^{\circ} \mathrm{C}$. After removal of the medium, cells were washed with ice-cold $\mathrm{NaCl}$-containing medium. Extracellular and cell-surface adsorbed ${ }^{36} \mathrm{Cl}$ were maximally removed with five $1.5-\mathrm{ml}$ washes. There was no reduction in residual cell-associated radioactivity with as many as nine total washes.

was temperature dependent with markedly reduced uptake at $4^{\circ} \mathrm{C}$ as compared to $37^{\circ} \mathrm{C}$ (Fig. $3 \mathrm{~A}$ ). Equilibrium cell content of ${ }^{36} \mathrm{Cl}$ was attained by $30 \mathrm{~min}$ (Fig. $3 \mathrm{~B}$ ), indicating relatively slow influx of this anion. In four studies, influx of ${ }^{36} \mathrm{Cl}$ over the initial $10 \mathrm{~min}$ at $37^{\circ} \mathrm{C}$ averaged $3.9 \pm 0.2 \%$ of equilibrium $\mathrm{Cl}^{-}$ content per minute. This indicates that, over the first minute after incubation of $\mathrm{Cl}^{-}$-depleted cells in $\mathrm{Cl}^{-}$-containing medium, there is little change in cellular $\mathrm{Cl}^{-}$content (Fig. $3 \mathrm{~B}$ ). After incubation for $30 \mathrm{~min}$ in ${ }^{36} \mathrm{Cl}$, disruption of cells by sonication and centrifugation at $100,000 \mathrm{~g}$ revealed that $>95 \%$ of radioactivity was present in the supernatant.

Efflux of ${ }^{36} \mathrm{Cl}$ from preloaded cultured hepatocytes. After 60 min preloading of $\mathrm{Cl}^{-}$-depleted cells with ${ }^{36} \mathrm{Cl}$, subsequent efflux was found to be temperature dependent, with little efflux at $4^{\circ} \mathrm{C}$ as compared to $37^{\circ} \mathrm{C}$ (Fig. 4). Similar to uptake, efflux was a relatively slow event, and at $1 \mathrm{~min}$, over $75 \%$ of ${ }^{36} \mathrm{Cl}$ remained in hepatocytes ( 75 and $85 \%$ in two studies). This indicates that over the first minute after incubation of $\mathrm{Cl}^{-}$loaded cells in $\mathrm{Cl}^{-}$-depleted medium, a large inside to outside $\mathrm{Cl}^{-}$gradient is maintained.

Effect of $\mathrm{Cl}^{-}$gradients on BSP uptake by hepatocytes. The preceding results indicate that transient unidirectional $\mathrm{Cl}^{-}$gradients can be established in cultured hepatocytes. Initial uptake of ${ }^{35} \mathrm{~S}$-BSP was quantified at 4 or $37^{\circ} \mathrm{C}$ over $1 \mathrm{~min}$ under conditions in which extracellular $\mathrm{Cl}^{-}\left(\mathrm{Cl}_{e}\right)$ and intracellular $\mathrm{Cl}^{-}\left(\mathrm{Cl}_{\mathrm{i}}\right)$ were varied as described above. Under control conditions, with normal content of $\mathrm{Cl}_{\mathrm{e}}$ and $\mathrm{Cl}_{\mathrm{i}}$, initial uptake of ${ }^{35} \mathrm{~S}-\mathrm{BSP}$ by hepatocytes was $8.13 \pm 2.65 \mathrm{pmol} / \mathrm{mg}$ protein $/ \mathrm{min}(n=4)$. As seen in Fig. 5 , in the absence of extracellular $\mathrm{Cl}^{-}$, initial uptake of ${ }^{35} \mathrm{~S}$-BSP was significantly reduced under conditions of normal $(n=4)$ or depleted intracellular $\mathrm{Cl}^{-}(n=4)$ as compared with control $(P<0.01$ and $P<0.001$, respectively). Initial uptake of ${ }^{35} \mathrm{~S}-\mathrm{BSP}$ with $\mathrm{Cl}_{\mathrm{e}}>\mathrm{Cl}_{\mathrm{i}}$ did not differ significantly from control $(n=4, P>0.08)$. These results indicate that there is no stimulation of BSP uptake by transmembrane $\mathrm{Cl}^{-}$gradients, suggesting that BSP transport is not coupled to chloride transport.

Chloride-dependent binding of ${ }^{35} S$-BSP to the surface of cultured hepatocytes. To determine whether extracellular $\mathrm{Cl}^{-}$ might directly modulate the affinity of BSP for its hepatocyte 

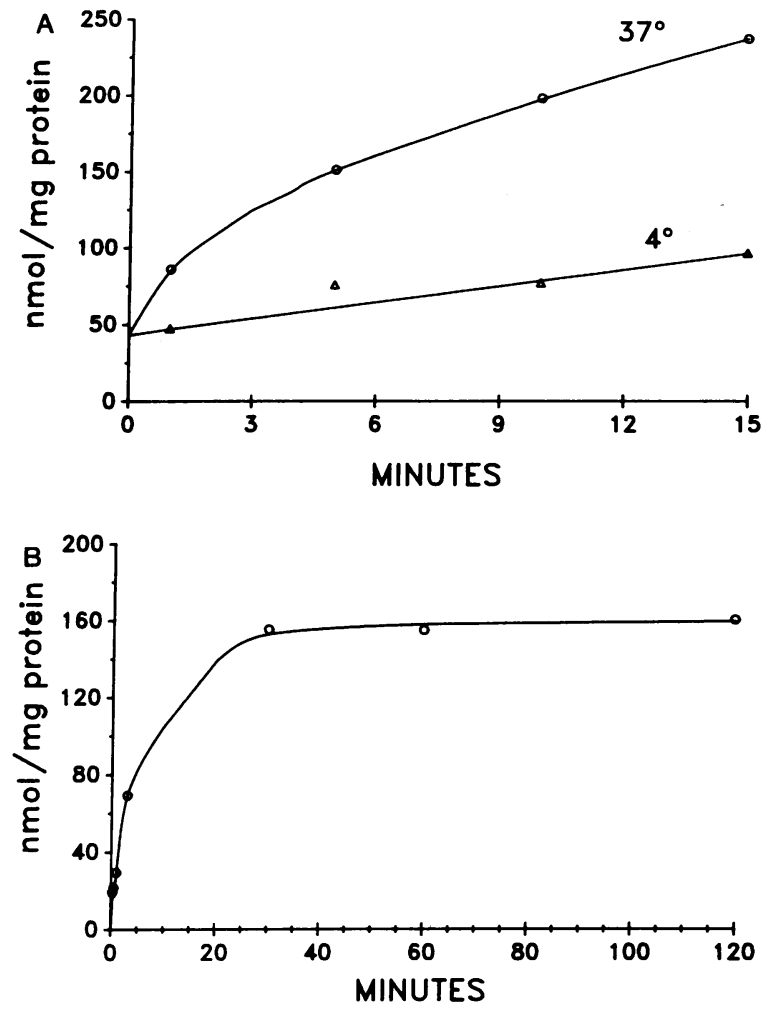

Figure 3. Uptake of ${ }^{36} \mathrm{Cl}$ by short-term cultured rat hepatocytes. Short-term cultured rat hepatocytes were incubated in sucrose-substituted medium for $30 \mathrm{~min}$ at $37^{\circ} \mathrm{C}$. Cells were then incubated in $1 \mathrm{ml}$ of $135 \mathrm{mM} \mathrm{Na}{ }^{36} \mathrm{Cl}(1 \mu \mathrm{Ci})$. At the indicated times, medium was removed and cells were washed rapidly five times with $1.5 \mathrm{ml}$ of ice-cold $\mathrm{NaCl}$-containing medium. Cells were then harvested, and radioactivity was determined. $(A)$ Initial uptake of ${ }^{36} \mathrm{Cl}$ at 4 and $37^{\circ} \mathrm{C}$ reveals temperature dependence. This is a representative study of four that were performed. $(B)$ Prolonged study reveals that equilibrium was attained by $30 \mathrm{~min}$. Initial influx of ${ }^{36} \mathrm{Cl}$ was relatively slow, and averaged $3.9 \pm 0.2 \%$ of equilibrium $\mathrm{Cl}^{-}$content per minute. This is a representative study of four that were performed.

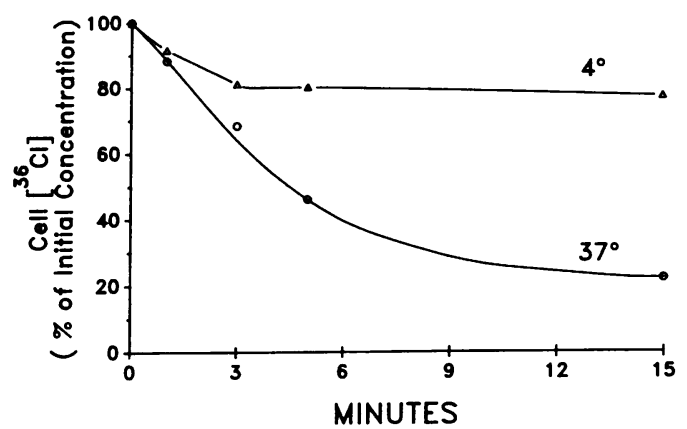

Figure 4. Efflux of ${ }^{36} \mathrm{Cl}$ from preloaded cultured hepatocytes. Cells were incubated in sucrose-substituted medium for $30 \mathrm{~min}$ at $37^{\circ} \mathrm{C}$. They were then incubated for $60 \mathrm{~min}$ at $37^{\circ} \mathrm{C}$ in $1 \mathrm{ml}$ of $135 \mathrm{mM}$ $\mathrm{Na}^{36} \mathrm{Cl}(2 \mu \mathrm{Ci})$. They were washed with $1.5 \mathrm{ml}$ of ice-cold sucrosesubstituted medium five times and incubated for various times in this medium at 4 or $37^{\circ} \mathrm{C}$. The fraction of initial cell-associated ${ }^{36} \mathrm{Cl}$ remaining in cells over time is plotted, and reveals that at $1 \mathrm{~min}$, over $75 \%$ of ${ }^{36} \mathrm{Cl}$ remained in hepatocytes. This is a representative study of two that were performed.

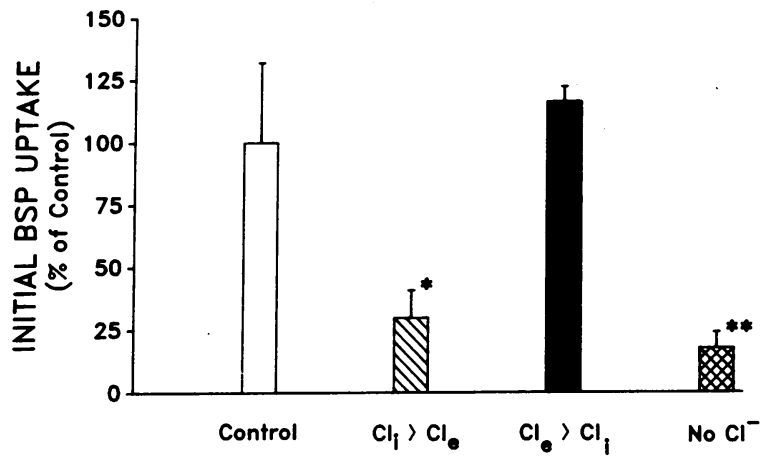

Figure 5. Effect of transmembrane $\mathrm{Cl}^{-}$gradients on initial ${ }^{35} \mathrm{~S}-\mathrm{BSP}$ uptake by short-term cultured rat hepatocytes. Initial uptake of ${ }^{35} \mathrm{~S}$ BSP was determined over 1 min under four conditions: $(a)$ control, normal content of extracellular $\mathrm{Cl}^{-}\left(\mathrm{Cl}_{\mathrm{e}}\right)$ and intracellular $\mathrm{Cl}^{-}\left(\mathrm{Cl}_{\mathrm{i}}\right)$, (b) $\mathrm{Cl}_{\mathrm{i}}>\mathrm{Cl}_{e}$, (c) $\mathrm{Cl}_{\mathrm{e}}>\mathrm{Cl}_{\mathrm{i}}$, and (d) depletion of both intracellular and extracellular $\mathrm{Cl}^{-}$(no $\mathrm{Cl}^{-}$). Under control conditions with normal content of $\mathrm{Cl}_{\mathrm{e}}$ and $\mathrm{Cl}_{\mathrm{i}}$, initial ${ }^{35} \mathrm{~S}-\mathrm{BSP}$ uptake was $8.13 \pm 2.65 \mathrm{pmol} / \mathrm{mg}$ protein per min. In the absence of extracellular $\mathrm{Cl}^{-}$, uptake of ${ }^{35} \mathrm{~S}-\mathrm{BSP}$ was reduced under conditions of normal or depleted intracellular $\mathrm{Cl}^{-}$. Initial uptake of ${ }^{35} \mathrm{~S}-\mathrm{BSP}$ with $\mathrm{Cl}_{\mathrm{e}}>\mathrm{Cl}_{\mathrm{i}}$ did not differ significantly from control. There was no evidence for stimulation of BSP uptake by $\mathrm{Cl}^{-}$gradients suggesting that BSP transport was not coupled to chloride transport. Data is presented as mean \pm SEM of four studies. ${ }^{*} P<0.01$ as compared with control. ${ }^{* *} P<0.001$ as compared with control.

transporter, binding of ${ }^{35} \mathrm{~S}$-BSP to hepatocytes was determined at $4^{\circ} \mathrm{C}$ in the presence of a 15 -fold molar excess of albumin in $\mathrm{NaCl}$-containing or sucrose-substituted media. Data was computer analyzed by the method of Munson and Rodbard (27) and, in both media, the fit was optimal when a single class of binding sites was used. Nonspecific binding is determined directly by this method, and was $0.11 \pm 0.06 \%$ of total ligand in the presence of $\mathrm{NaCl}$, and $0.07 \pm 0.04 \%$ in sucrose-substituted medium $(P>0.6)$. The affinity of BSP for hepatocytes was significantly higher in the presence of $\mathrm{Cl}^{-}$than in sucrose-substituted medium $\left(K_{\mathrm{a}}=3.2 \pm 0.8 \mu \mathrm{M}^{-1}\right.$ vs. $0.42 \pm 0.09 \mu \mathrm{M}^{-1} ; n$ $=5, P<0.02$ ) (Fig. 6). Under these conditions, there was no difference in the number of binding sites $(10.2 \pm 1.7$ vs. $12.4 \pm 0.9 \mathrm{pmol} / \mathrm{mg}$ protein; $n=5, P>0.2$ ).

Equilibrium binding studies of ${ }^{35} S$-BSP to BSA. Changes in apparent affinity of ${ }^{35} \mathrm{~S}$-BSP to the cell surface could reflect altered affinity of this ligand for BSA. For this reason, binding of ${ }^{35} \mathrm{~S}-\mathrm{BSP}$ to BSA was quantified to determine whether $\mathrm{Cl}^{-}$ influences the affinity of albumin for BSP. No significant difference was observed in the affinity of BSA for BSP between $\mathrm{NaCl}$-containing and sucrose-substituted media with $K_{\mathrm{a}}$ of $0.33 \pm 0.06 \mu \mathrm{M}^{-1}$ and $0.59 \pm 0.08 \mu \mathrm{M}^{-1}$, respectively $(n=4, P$ $>0.1$ ).

Saturation kinetics of ${ }^{35} S$-BSP uptake. As seen in Fig. 7, in $\mathrm{NaCl}$-containing medium, initial uptake of ${ }^{35} \mathrm{~S}$-BSP displayed saturation kinetics as previously described (12). With isosmotic substitution of $\mathrm{NaCl}$ by sucrose, there was little cell uptake at any concentration of ${ }^{35} \mathrm{~S}$-BSP. That is, the transport mechanism for BSP was functionally inactive.

Influence of cellular pH on uptake of ${ }^{36} \mathrm{Cl}$ and ${ }^{35} \mathrm{~S}$-BSP. Unidirectional $\mathrm{pH}$ gradients were formed to determine the effect of cellular $\mathrm{pH}$ on initial uptake of ${ }^{36} \mathrm{Cl}$. There was no effect of inwardly or outwardly directed gradients of $\mathrm{pH}(6-8)$ on initial uptake of ${ }^{36} \mathrm{Cl}(26.0 \pm 1.0$ vs. $27.0 \pm 5.0 \mathrm{nmol} / \mathrm{min}$ per $\mathrm{mg}$ pro- 


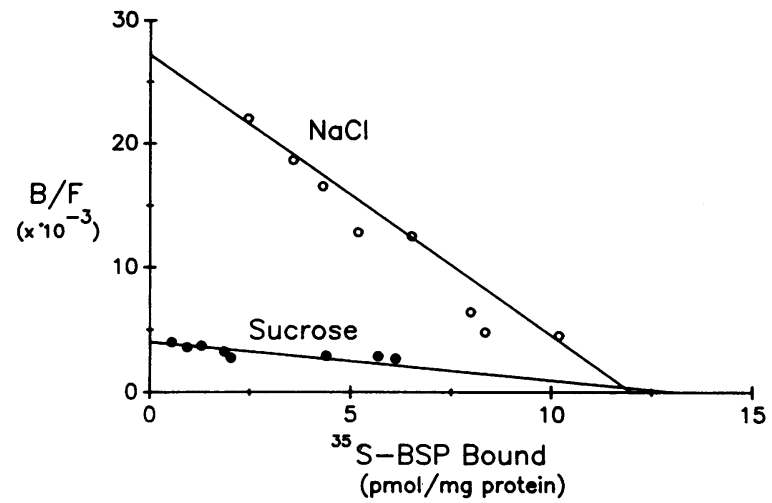

Figure 6. Chloride-dependent binding of ${ }^{35} \mathrm{~S}-\mathrm{BSP}$ to the surface of short-term cultured rat hepatocytes. Binding assays were performed at varied concentrations of ${ }^{35} \mathrm{~S}-\mathrm{BSP}(0.08-3.2 \mu \mathrm{M})$ at $4^{\circ} \mathrm{C}$ in the presence of a 15-fold molar excess of BSA in NaCl-containing or sucrosesubstituted media keeping the ratio of albumin to BSP constant to minimize changes in the fraction of unbound ligand. Results were analyzed by the LIGAND computer program as described by Munson and Rodbard and plotted according to the method of Scatchard. The affinity of BSP for hepatocytes was significantly higher in the presence of $\mathrm{Cl}^{-}$than in sucrose-substituted medium. Under these conditions, there was no difference in the number of binding sites. In this representative study of five, $K_{\mathrm{a}}$ in the presence and absence of $\mathrm{Cl}^{-}$was 1.6 vs. $0.17 \mu \mathrm{M}^{-1}$, and the number of binding sites was 11.8 vs. 12.6 $\mathrm{pmol} / \mathrm{mg}$ protein.

tein; $n=3, P>0.05)$. However, initial uptake of ${ }^{35} \mathrm{~S}-\mathrm{BSP}$ with an inwardly directed $\mathrm{H}^{+}$gradient $(n=4)$ (outwardly directed $\mathrm{OH}^{-}$gradient) was approximately twice that with an outwardly directed $\mathrm{H}^{+}$gradient $(n=4)$ (inwardly directed $\mathrm{OH}^{-}$gradient) $(P<0.02)$ (Fig. 8).

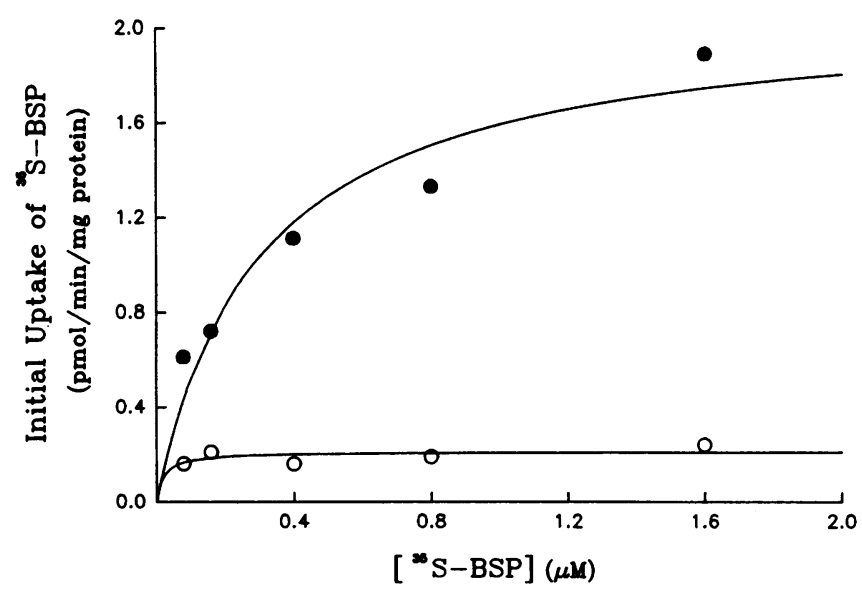

Figure 7. Saturation of initial ${ }^{35} \mathrm{~S}-\mathrm{BSP}$ uptake by cultured rat hepatocytes. Initial uptake of varied concentrations of ${ }^{35} \mathrm{~S}-\mathrm{BSP}(0.08-1.6$ $\mu \mathrm{M}$ ) was determined in $\mathrm{NaCl}$-containing or sucrose-substituted media as in Fig. 1, keeping the ratio of BSA to BSP constant. Results were computer fit to a single class of binding sites by a nonlinear least squares regression method. In this figure, the circles represent experimental data, and the lines represent the computer fit to the data. In this representative study of three, in $\mathrm{NaCl}$-containing medium $(\bullet-\bullet), K_{\mathrm{m}}$ was $0.31 \mu \mathrm{M}$ and $V_{\max }$ was $2.1 \mathrm{pmol} / \mathrm{mg}$ protein per min. In sucrose-substituted medium ( $0-0$ ), there was little BSP uptake at any concentration, suggesting that the transport mechanism was functionally inactive.

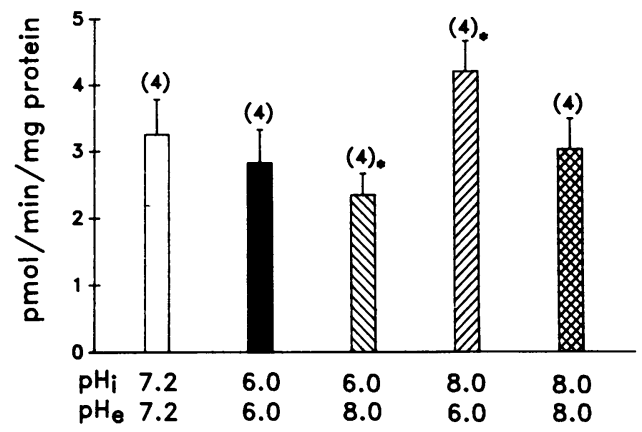

Figure 8. Effect of pH on initial uptake of ${ }^{35} \mathrm{BSP}$ by short-term cultured rat hepatocytes. Modified SFM was prepared in which the $\mathrm{pH}$ of the medium was adjusted to $\mathrm{pH} 6.0$ or 8.0 with $1 \mathrm{~N} \mathrm{NaOH}$. Cells were washed with either $\mathrm{pH} 6.0$ or 8.0 medium and incubated for 30 min at $37^{\circ} \mathrm{C}$ in the corresponding medium. Unidirectional pH gradients were established by incubating the $\mathrm{OH}^{-}$-loaded or -depleted cells in medium of the opposite $\mathrm{pH}$. Uptake of ${ }^{35}$-BSP was determined over $5 \mathrm{~min}$. With an inwardly directed $\mathrm{H}^{+}$gradient (outwardly directed $\mathrm{OH}^{-}$gradient), there was an approximately twofold increase in the initial ${ }^{35} \mathrm{~S}$-BSP uptake as compared to an outwardly directed $\mathrm{H}^{+}$ gradient (inwardly directed $\mathrm{OH}^{-}$gradient), suggesting that a component of BSP uptake is associated with $\mathrm{H}^{+}$cotransport or $\mathrm{OH}^{-}$exchange. However, indirect linkage to other anion exchangers must be considered. Results are presented as mean \pm SEM. The number of studies performed is in parentheses. ${ }^{*} P<0.02$.

\section{Discussion}

Previous studies revealed that initial uptake of bilirubin and BSP by short-term cultured rat hepatocytes, and isolated perfused rat liver was markedly reduced after substitution of $\mathrm{Cl}^{-}$ by gluconate or $\mathrm{HCO}_{3}^{-}$, but was unaltered after substitution of $\mathrm{Na}^{+}$in medium by other inorganic cations (12). These investigations suggested a role for inorganic anions, particularly $\mathrm{Cl}^{-}$, in hepatic organic anion uptake. Hepatocyte uptake of other compounds such as ${ }^{99 \mathrm{~m}} \mathrm{Tc}$-iminodiacetic acid derivatives, was found to be independent of $\mathrm{Cl}^{-}$concentration (30), indicating specificity of this finding for particular organic anions. Although replacement of $\mathrm{NaCl}$ in medium by sucrose may osmotically shrink cells $(19,20)$, this is not the mechanism by which BSP uptake is reduced with sucrose substitution. As initial uptake of BSP is quantified at a time well before steady state has been established (12), one would not expect a large effect upon alteration of cell size. In support of this, shrinkage of cells with $1 \mathrm{M}$ mannitol had little effect on initial uptake of BSP. Although others have suggested that BSP uptake is electrogenic $(13,31)$, the finding of normal BSP uptake in KCl-substituted medium in the presence and absence of valinomycin suggests that this is not the case.

In the present study, BSP transport has been determined in cells in which inside vs. outside $\mathrm{pH}$ gradients have been established. These studies suggest that a component of BSP uptake is associated with $\mathrm{H}^{+}$cotransport or $\mathrm{OH}^{-}$exchange. However, indirect linkage to other anion exchangers (e.g., hydroxyl/sulfate) must be considered. DIDS, an inhibitor of various anion exchangers, is an effective inhibitor of hepatocyte BSP uptake (12). BSP transport has also been determined in cells in which inside vs. outside $\mathrm{Cl}^{-}$gradients have been established. Initial uptake of BSP in the absence of extracellular $\mathrm{Cl}^{-}$is significantly decreased regardless of the concentration of intracellular $\mathrm{Cl}^{-}$. In contrast to results with $\mathrm{pH}$ gradients, there was no stimula- 
tion of initial uptake of BSP with inwardly or outwardly directed $\mathrm{Cl}^{-}$gradients. This suggests that BSP transport is not coupled to $\mathrm{Cl}^{-}$transport. Although nonspecific alterations in cell surface membrane function may be considered with $\mathrm{Cl}^{-}$ and $\mathrm{OH}^{-}$manipulation, binding and internalization of asialoorosomucoid are not affected under similar conditions $(16,27)$.

Several other $\mathrm{Cl}^{-}$-dependent organic anion transport systems (e.g., urate transport by kidney [32]) are characterized by stimulation of organic anion uptake by inside to outside $\mathrm{Cl}^{-}$ gradients. The present study reveals that uptake of BSP by hepatocytes does not involve $\mathrm{Cl}^{-}$/organic anion exchange or $\mathrm{Cl}^{-} /$ organic anion cotransport. Rather, $\mathrm{Cl}^{-}$modulates the affinity of BSP for its hepatocyte transporter. The affinity of BSP for hepatocytes is $\sim 10$-fold higher in the presence of extracellular $\mathrm{Cl}^{-}$than in sucrose-substituted medium. The number of cell surface binding sites is unaffected. The affinity of BSP for cells is also $\sim 10$-fold that of its affinity for albumin in $\mathrm{Cl}^{-}$-containing medium. This may help to explain the rapid, saturable transfer of albumin-bound BSP to hepatocytes. In the absence of extracellular chloride, this difference in affinities of BSP for cells and albumin is lost. As albumin is in excess of cell surface binding sites, little BSP is transferred to cells. Determination of saturation kinetics reveals functional inactivation of the transport mechanism. It must be considered that because these cellsurface binding studies were performed in the presence of albumin, alterations in apparent affinity of ligand to the cell surface could actually represent altered affinity of ligand to albumin. That this is not the case is seen from equilibrium binding studies which revealed no significant difference in the affinity of BSA for BSP in the presence or absence of $\mathrm{Cl}^{-}$. This is in agreement with previous results of Blauer and associates (33) who found no influence of $\mathrm{Cl}^{-}$on bilirubin binding to human serum albumin as determined by circular dichroism. In contrast to results with bilirubin and $\mathrm{BSP}, \mathrm{Cl}^{-}$competes for the high-affinity binding site of medium-chain fatty acids to human serum albumin (34). This finding is in agreement with the demonstration of different binding sites on albumin for bilirubin/BSP and fatty acids (35). A similar chloride effect on hepatocyte transport has been described by several other investigators. Duffy et al. (36) found maximal taurocholate uptake into mixed liver plasma membrane vesicles in the presence of chloride as compared to results in the presence of more permeant and less permeant anions. Meier et al. (37) found highest initial uptake rates of taurocholate into rat canalicular membrane vesicles in the presence of chloride. Novak et al. (38) made similar observations in studies of taurocholate transport by human liver basolateral plasma membrane vesicles. Whether this stimulation of taurocholate transport by chloride represents altered interaction with its membrane carrier is unknown.

A number of other $\mathrm{Cl}^{-}$-dependent organic anion transport systems which do not involve $\mathrm{Cl}^{-}$/organic anion exchange have been described. In pigeon red blood cells, $\mathrm{Cl}^{-}$increases the affinity of $\mathrm{Na}^{+}$for the glycine transporter with subsequent enhancement of glycine uptake $(39,40)$. Selhub et al. (41) described anion-induced stabilization of endogenous folate-binding protein complex in brush border membranes from rat kidney, with chloride as the most effective anion. In rat brain synaptosomes, substitution of $\mathrm{Cl}^{-}$by anions such as acetate, isethionate, and sulfate reduced the high-affinity uptake of neurotransmitters such as dopamine, norepinephrine, serotonin, and gamma-aminobutyric acid (42). It was suggested that $\mathrm{Cl}^{-}$ might modulate the affinity of these neurotransmitters for their transporter (42-44).

The present study indicates that extracellular $\mathrm{Cl}^{-}$modulates the affinity of BSP for its hepatocyte transporter. This effect of $\mathrm{Cl}^{-}$on BSP uptake does not correlate with transport of $\mathrm{Cl}^{-}$nor with altered interaction of albumin with the organic anion. These results are consistent with binding of $\mathrm{Cl}^{-}$to the liver cell organic anion transporter with consequent conformational change in its organic anion binding domain. This hypothesis, however, is speculative. Identification of the liver cell plasma membrane protein(s) comprising the organic anion transporter and functional reconstitution in vitro may be necessary for the ultimate elucidation of the role of $\mathrm{Cl}^{-}$in this process.

\section{Acknowledgments}

The authors wish to acknowledge the helpful advice of Dr. Vern Schramm in performing equilibrium binding studies.

This work was supported by National Institutes of Health grants DK-23026, DK-41296, and DK-07218.

\section{References}

1. Gray, R. D., and S. S. Stroupe. 1978. Kinetics and mechanisms of bilirubin binding to human serum albumin. J. Biol. Chem. 253:4370-4377.

2. Baker, K. J., and S. E. Bradley. 1966. Binding of sulfobromophthalein sodium by plasma albumin. Its role in hepatic sulfobromophthalein extraction. $J$. Clin. Invest. 45:281-287.

3. Scharschmidt, B. F., J. G. Waggoner, and P. D. Berk. 1975. Hepatic organic anion uptake in the rat. J. Clin. Invest. 56:1280-1292.

4. Stollman, Y. R., U. Gartner, L. Theilmann, N. Ohmi, and A. W. Wolkoff. 1983. Hepatic bilirubin uptake in the isolated perfused rat liver is not facilitated by albumin binding. J. Clin. Invest. 72:718-723.

5. Levi, A. J., Z. Gatmaitan, and I. M. Arias. 1969. Two hepatic cytoplasmic fractions, $\mathrm{Y}$ and $\mathrm{Z}$, and their possible role in the hepatic uptake of bilirubin, sulfobromophthalein, and other anions. J. Clin. Invest. 48:2156-2167.

6. Habig, W. H., M. J. Pabst, G. Fleischner, Z. Gatmaitan, I. M. Arias, and W. B. Jakoby. 1974. The identity of glutathione-S-transferase B with ligandin, a major binding protein of liver. Proc. Natl. Acad. Sci. USA. 71:3879-3882.

7. Wolkoff, A. W., and C. T. Chung. 1980. Identification, purification, and partial characterization of an organic anion binding protein from rat liver cell plasma membrane. J. Clin. Invest. 65:1152-1161.

8. Wolkoff, A. W., A. Sosiak, H. C. Greenblatt, J. Van Renswoude, and R. J. Stockert. 1985. Immunological studies of an organic anion-binding protein isolated from rat liver cell plasma membrane. J. Clin. Invest. 76:454-459.

9. Miccio, M., G. Baldini, V. Basso, B. Gazzin, G. C. Lunazzi, C. Tiribelli, and G. L. Sottocasa. 1989. Bilitranslocase is the protein responsible for the electrogenic movement of sulfobromophthalein in plasma membrane vesicles from rat liver: immunochemical evidence using mono- and polyclonal antibodies. Biochim. Biophys. Acta. 981:115-120.

10. Stremmel, W., M. A. Gerber, V. Glezerov, S. N. Thung, S. Kochwa, and P. D. Berk. 1983. Physicochemical and immunohistological studies of a sulfobromophthalein and bilirubin-binding protein from rat liver plasma membrane. $J$. Clin. Invest. 71:1796-1805.

11. Berk, P. D., B. J. Potter, and W. Stremmel. 1987. Role of plasma membrane ligand-binding proteins in the hepatocellular uptake of albumin-bound organic anions. Hepatology (Baltimore). 7:165-176.

12. Wolkoff, A. W., A. C. Samuelson, K. L. Johansen, R. Nakata, D. M Withers, and A. Sosiak. 1987. Influence of $\mathrm{Cl}^{-}$on organic anion transport in short-term cultured rat hepatocytes and isolated perfused rat liver. J. Clin. Invest. 79:1259-1268

13. Potter, B. J., B. F. Blades, M. D. Shepard, S. M. Thung and P. D. Berk. 1987. The kinetics of sulfobromophthalein uptake by rat liver sinusoidal vesicles. Biochim. Biophys. Acta. 898:159-171.

14. Scharschmidt, B. F., and J. E. Stephens. 1981. Transport of sodium, chloride, and taurocholate by cultured rat hepatocytes. Proc. Natl. Acad. Sci. USA. 78:986-990.

15. Scharschmidt, B. F., R. W. Van Dyke, and J. E. Stephens. 1982. Chloride transport by intact rat liver and cultured rat hepatocytes. Am. J. Physiol. 242:G628-G633. 
16. Wolkoff, A. W., R. D. Klausner, G. Ashwell, and J. Harford. 1984. Intracellular segregation of asialoglycoproteins and their receptor: a prelysosomal event subsequent to dissociation of the ligand-receptor complex. J. Cell Biol. 98:375-381.

17. Kurisu, H., P. Nilprabhassorn, and A. W. Wolkoff. 1989. Preparation of ${ }^{35}$ S-sulfobromophthalein of high specific activity. Anal. Biochem. 179:72-74.

18. Lowry, O. H., N. J. Rosebrough, A. L. Farr, and R. J. Randall. 1951. Protein measurement with the Folin phenol reagent. J. Biol. Chem. 193:265-275.

19. Novak, J. M., P. M. Cala, D. M. Ward, S. S. Buys, and J. Kaplan. 1988.

Regulatory volume decrease in alveolar macrophages: cation loss is not correlated with changes in membrane recycling. J. Cell. Physiol. 137:243-250.

20. Corasanti, J. G., D. Gleeson, and J. L. Boyer. 1990. Effects of osmotic stresses on isolated rat hepatocytes. I. Ionic mechanisms of cell volume regulation. Am. J. Physiol. 258:G290-G298.

21. Claret, M., and J. L. Mazet. 1972. Ionic fluxes and permeabilities of cell membranes in rat liver. J. Physiol. (Lond.). 223:279-295.

22. Bracht, A., A. Kelmer Bracht, A. J. Schwab, and R. Scholz. 1981. Transport of inorganic anions in perfused rat liver. Eur. J. Biochem. 114:471-479.

23. Weisiger, R., J. Gollan, and R. Ockner. 1981. Receptor for albumin on the liver cell surface may mediate uptake of fatty acids and other albumin-bound substances. Science (Wash. DC). 211:1048-1051.

24. Schramm, V. L. 1976. Comparison of initial velocity and binding data for allosteric adenosine monophosphate nucleosidase. J. Biol. Chem. 251:34173424.

25. Whitlam, J. B., and K. F. Brown. 1981. Ultrafiltration in serum protein binding determinations. J. Pharmacol. Sci. 70:146-150.

26. Barré, J., J. M. Chamouard, G. Houin, and J. P. Tillement. 1985. Equilibrium dialysis, ultrafiltration, and ultracentrifugation compared for determining the plasma-protein-binding characteristics of valproic acid. Clin. Chem. 31:6064

27. Samuelson, A. C., R. J. Stockert, A. B. Novikoff, P. M. Novikoff, J. C. Saez, D. C. Spray, and A. W. Wolkoff. 1988. Influence of cytosolic pH on receptor-mediated endocytosis of asialoorosomucoid. Am. J. Physiol. 254:C829C838.

28. Snedecor, G. W., and W. G. Cochran. 1980. Statistical Methods. Seventh ed. The Iowa State University Press, Ames, IA.

29. Munson, P. J., and D. Rodbard. 1980. LIGAND: A versatile computerized approach for characterization of ligand-binding systems. Anal. Biochem. 107:220-239.

30. Lan, J. A., L. R. Chervu, K. L. Johansen, and A. W. Wolkoff. 1988.
Uptake of technetium $99 \mathrm{~m}$ hepatobiliary imaging agents by cultured rat hepatocytes. Gastroenterology. 95:1625-1631.

31. Sottocasa, G. L., G. Baldini, G. Sandri, G. Lunazzi, and C. Tiribelli. 1982 Reconstitution in vitro of sulfobromophthalein transport by bilitranslocase. Bio chim. Biophys. Acta. 685:123-128.

32. Kahn, A. M., S. Harnath, and E. J. Weinman. 1985. Urate and p-aminohippurate transport in rat renal basolateral vesicles. Am. J. Physiol. 249:F654 F661.

33. Blauer, G., and D. Harmatz. 1972. Optical properties of bilirubin-serum albumin complexes in aqueous solution. Biochim. Biophys. Acta. 278:89-100.

34. Honore, B., and R. Brodersen. 1987. Detection of carrier heterogeneity by rate of ligand dialysis: medium-chain fatty acid interaction with human serum albumin and competition with chloride. Anal. Biochem. 171:55-66.

35. Berde, C. B., B. S. Hudson, R. D. Simoni, and L. A. Sklar. 1979. Human serum albumin: spectroscopic studies of binding and proximity relationships for fatty acids and bilirubin. J. Biol. Chem. 254:391-400.

36. Duffy, M. C., B. L. Blitzer, and J. L. Boyer. 1983. Direct determination of the driving forces for taurocholate uptake into rat liver plasma membrane vesicles. J. Clin. Invest. 72:1470-1481.

37. Meier, P. J., A. St. Meier-Abt, C. Barrett, and J. L. Boyer. 1984. Mechanisms of taurocholate transport in canalicular and basolateral rat liver plasma membrane vesicles. J. Biol. Chem. 259:10614-10622.

38. Novak, D. A., F. C. Ryckman, and F. J. Suchy. 1989. Taurocholate transport by basolateral plasma membrane vesicles isolated from human liver. Hepatology (Baltimore). 10:447-453.

39. Imler, J. R., and G. A. Vidaver. 1972. Anion effects on glycine entry into pigeon red blood cells. Biochim. Biophys. Acta. 288:153-165.

40. King, P. A., and R. B. Gunn. 1989. Na- and Cl-dependent glycine transport in human red blood cells and ghosts. J. Gen. Physiol. 93:321-342.

41. Selhub, J., A. C. Gay, and I. H. Rosenberg. 1979. Effect of anions on folate binding by isolated brush border membranes from rat kidney. Biochim. Biophys. Acta. 557:372-384.

42. Shank, R. P., C. R. Schneider, and J. J. Tighe. 1987. Ion dependence of neurotransmitter uptake: inhibitory effects of ion substitutes. J. Neurochem. 49:381-388.

43. Pastuszko, A., D. F. Wilson, and M. Erecinska. 1982. Energetics of $\gamma$ aminobutyrate transport in rat brain synaptosomes. J. Biol. Chem. 257:75147519.

44. Erecinska, M., D. Wantorsky, and D. F. Wilson. 1983. Aspartate transport in synaptosomes from rat brain. J. Biol. Chem. 258:9069-9077. 